\title{
Facilities Development and Socialization of Bule-Brazilians in Buckets (Guide for The Event of Community Economic Independence)
}

\author{
Efta Dhartikasari Priyana, \\ Said Salim Dahda ${ }^{2}$ \\ Wisda Mulyasari ${ }^{3}$ \\ Dzakiyah Widyaningrum ${ }^{4}$ \\ Moh. Dian Kurniawan ${ }^{5}$ \\ Khoirul Aman Makhrudy ${ }^{6}$ \\ ${ }^{1-6}$ Program Studi Teknik Industri, Fakultas Teknik, Universitas Muhammadiyah Gresik \\ eftadhartikasari@umg.ac.id
}

\begin{abstract}
ABSTRAK
Gresik, salah satu kota industri di Indonesia telah mencatat adanya lebih dari 1000 pekerja telah dirumahkan. Semakin membengkaknya pengangguran di Gresik membuat pemerintah harus ekstra kerja keras membantu permasalahan masyarakat. Namun beban akan ketidakberdayaan masyarakat ini tidak serta merta bisa dilimpahkan semua ke pemerintah. Kendati pemerintah yang masih sangat sibuk dengan kasus covid-19 yang tak kunjung terselesaikan. Pengabdian Masyarakat yang diusulkan oleh tim Teknik Industri UMG mengambil tema Budidaya Ikan dalam ember (Fish farming in buckets) yang lebih dikenal dengan sebutan aquaponik. Konsep Fish farming in buckets sendiri yakni menyatukan tanaman dan ikan dalam ember, sehingga menghasilkan simbiosis mutuallisme yang sangat menguntungkan kedua belah pihak. Sasaran objek penelitian ini akan dilakukan di Prodi Teknik Industri Universitas Muhammadiyah Gresik (TI-UMG) dengan memberikan undangan kepada warga Yosowilangun Gresik khususnya kelompok FAMILY WELFARE DEVELOPMENT dan yayasan Yatim Mandiri. Alasan kenapa pembekalan lebih dipilih ke kelompok FAMILY WELFARE DEVELOPMENT dan Yatim Mandiri, tak lain karena FAMILY WELFARE DEVELOPMENT merupakan kumpulan ibu-ibu rumah tangga dimana kemungkinan disini akan ada beberapa dari kepala keluarganya yang di PHK. Dan Yayasan Yatim Mandiri disini untuk mensupport dalam peningkatan kemandirian perekonomian kelompok yatim piatu.
\end{abstract}

Kata kunci: Fish farming in buckets, Lele, Bayam Brazil

\begin{abstract}
Gresik, one of the industrial cities in Indonesia, has recorded that more than 1000 workers have been laid off. The increasing unemployment in Gresik makes the government have to work extra hard to help the community's problems. However, the burden of this community's powerlessness cannot be transferred to the government all the time. Even though the government is still very busy with the unresolved COVID-19 cases. The Community Service proposed by the UMG Industrial Engineering team took the theme of Fish Cultivation in Buckets (Fish farming in buckets), which is better known as aquaponics. The concept of Fish farming in buckets itself is to unite plants and fish in a bucket, resulting in a symbiotic mutualism that is very beneficial for both parties. The object of this research will be conducted at the Industrial Engineering Study Program, University of Muhammadiyah Gresik (TI-UMG) by giving invitations to residents of Yosowilangun Gresik, especially the FAMILY WELFARE DEVELOPMENT group and the Yatim Mandiri foundation. The reason why the debriefing is preferred to the FAMILY WELFARE DEVELOPMENT and Yatim Mandiri groups is none other than the fact that FAMILY WELFARE DEVELOPMENT is a collection of housewives where it is likely that some of the heads of their families will be laid off. And the Yatim Mandiri Foundation is here to support the improvement of the economic independence of the orphan group.
\end{abstract}

Keywords: Fish farming in buckets, Catfish, Brazil Spinach 


\section{INTRODUCTION}

COVID-19 pandemic attack that occurred in November 2019 has devastated the joints of the world economy, including Indonesia. This of course must be taken seriously, especially reinforced by the statement of the Minister of Finance Sri Mulayani that Indonesia has been hit by a recession of $2.9 \%$ in September $2020^{[1]}$. This attack caused quite a fatal turmoil, at least more than 3.05 million people were laid off (Termination of Employment).

Gresik, one of the small cities in East Java which has become an industrial icon, has also been affected by the COVID-19 pandemic. In addition to having held the red zone title for a long time due to COVID-19, the economic foundations of companies in the region are also worthy of attention. The Manpower Office (Disnaker) stated that at least 967 workers had experienced termination of employment (PHK) from 16 companies. This number does not include 263 workers from 7 companies who are currently furloughed ${ }^{[2]}$.

The number of layoffs (PHK) in several areas in Gresik, which actually almost happened, made the service team from the Industrial Engineering University of Muhammadiyah Gresik (TI-UMG) try to rack their brains in helping to handle the community's economic case. In order to carry out one of the duties of the Tri Dharma of Higher Education, and to become a servant of the state in society, the TIUMG team initiated a breakthrough in the agricultural-fishery world, namely Fish Cultivation in Buckets (Fish farming in buckets).

Fish farming in buckets is preferred to be proposed because it has many benefits. In addition to being very flexible for small areas, Fish farming in buckets costs are quite economical and can be done by anyone, and the results can be very profitable, both for personal consumption and for business. Fish farming in buckets or better known as aquaponics is an idea proposed by one of the Lampung State Polytechnic Lecturers, Juli Nursandi. Fish farming in buckets conceptualizes to place fish and plants in one package, namely a bucket, so that there is a symbiotic relationship of mutualism between plants and fish. Plants are planted to absorb the elements produced by fish so that it is more fertile, and fish eat the plants. Fish that can be raised in Budidakber are fish that are resistant to low oxygen levels such as catfish, catfish, sepat fish, betok fish, snakehead fish, and carp. While plants that can be used as media are all types of plants (kale, genjer and Brazilian spinach are prioritized $)^{[3]}$.

This devotion by taking the Fish farming in buckets theme will choose catfish as a means of learning media. Catfish is preferred over other fish because it has several advantages ${ }^{[4]}$ :

1. Catfish seeds are relatively easy to get and cheap

2. In reared in various containers and aquatic environments (more survival)

3. Can be kept in stagnant water and minimal water

4. Receive a variety of feed

5. Disease resistance

6. Fast growth

7. High nutritional content, every 100 grams contains (145 calories of energy; 15.45 grams of protein; 9.09 grams of fat; 65 milligrams of sodium)

Maintaining an economical but high nutritional value catfish in a good way can also break the perception of people who are afraid to eat catfish because most of them are kept in ponds. This catfish, which is very economical but has rich nutritional content, should be exploited by the community. Especially during the covid-19 outbreak which requires extra nutritional value but clean. Not only that, by keeping catfish, catfish can be processed again into chips, nuggets, and even other snacks that can be sold so as to produce more value.

Second, the planting medium chosen to combine catfish for the Fish farming in buckets system was Brazilian spinach. Brazilian spinach more than other crops because this plant is indeed the top priority recommended for planting in Fish farming in buckets. The Brazilian spinach plant or cooler with its Latin name Brazilian Spinach is indeed not a familiar item among Indonesian people. The price is expensive, making people think again to buy it. Moreover, there is local spinach which costs more than 5 times more expensive than Brazilian spinach. But this price looks reasonable, if we know the properties or content in Brazilian spinach itself.

Generally, spinach is an important vegetable for the brain. The content of minerals such as folic acid, vitamin A, vitamin B6, vitamin C and its antioxidants can help prevent neuronal and cognitive functions of the brain. Brazilian spinach itself has a high vitamin and mineral content, it can be said that in 100 grams it contains carotene 7-8 mg, vitamin C 60-120 mg 
Ferrum 4-9 mg, calcium 300-450 mg. Consuming spinach every day can meet the daily nutritional needs of the body.

The benefits of the mineral and vitamin content of Brazilian spinach include ${ }^{[5]}$ :

1. Flavonoids can reduce the risk of cancer by up to $34 \%$ and inhibit the development of cancer cells.

2. Magnesium for bone growth and strengthening as well as preventing bone fractures.

3. Increase the immune system Vitamin A functions as a component of white blood cells that function to fight infections or diseases that attack the body.

4. Can prevent constipation up to $20 \%, 5$ ). The content of folic acid can improve blood circulation.

5. Other content in spinach is beta carotene, xanten and lutein. These three substances are very useful for keeping the eyes healthy. In addition, consuming spinach regularly also prevents inflammation and eye irritation.

Fish farming in buckets is very useful, especially for the Gresik area which is famous for its minimal land. The proposed service for this internal target is shown to the FAMILY WELFARE DEVELOPMENT and Orphans groups. The reason for partnering with these two groups is that the first is for FAMILY WELFARE DEVELOPMENT, some FAMILY WELFARE DEVELOPMENT members have their families laid off so that this is intended to support the economy of families affected by layoffs. The two groups of Orphans, the main reason is to help the Foundation's economic independence so that it is not completely dependent on donors. They can be more productive and creative.

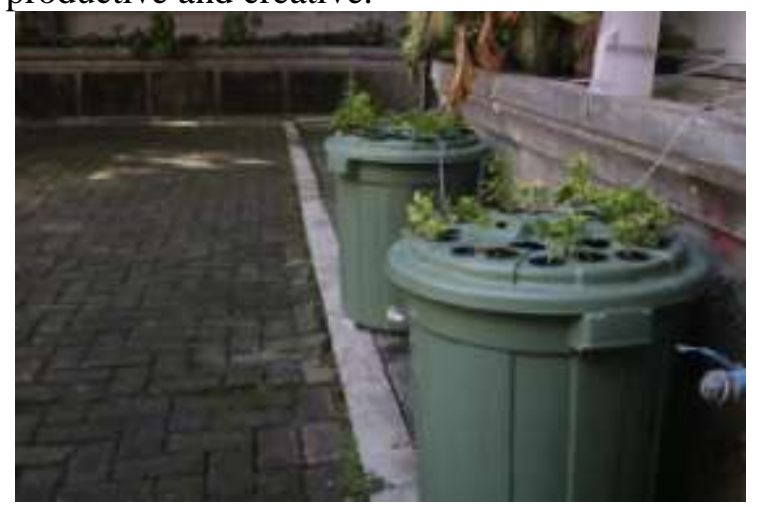

picture 1. Cultivating Brazilian Spinach and Catfish in a Bucket

\section{METHOD}

\section{Equipment}

In order to support the proposed internal community service environment for the Industrial Engineering Study Program, Muhammadiyah University of Gresik which is dedicated to fostering SMA/SMK, Orphanage, and PKK in 3 areas in Gresik (Manyar, Gresik District, Kebomas), several materials are needed to support the smooth running of service. this. Materials and equipment needed include you:

1. Equipment

1. Room for seminars

2. Room for the practice of making fertilizer

3. LCD

4. Laptops

2. Tools and Materials Required

1. 80 liter bucket

2. Coconut shell charcoal

3. Plastic cups

4. Catfish seed size $5-12 \mathrm{~cm}, 60-100$ heads

5. Tang

6. Small bendable wire

7. Brazilian spinach seeds

\section{Steps Of Cultivation In a Bucket}

There are several ways that will be carried out in the proposed FISH CULTIVATION IN A BUCKET proposal which will cooperate with . Petrokimia Gresik is as follows.

1. Make holes in 10-15 pieces of plastic cups with a soldering iron

2. Insert the bottom of the brazil spinach seedlings.

3. Put the kale in a glass, and fill the glass with coconut shell charcoal between $50-80 \%$ the size of the glass.

4. Cut a wire of approximately $12 \mathrm{~cm}$ to make a hook model that can be used as a cup holder in a bucket.

\section{For Media}

1. Fill 60 liters of water, let stand for approximately 1-2 days 
2. Enter the fish seeds, let stand 1-2 days

3. Frame a glass of brazil spinach on the side of the bucket.

\section{Fish Cultivation In a Bucket}

Fish farming in buckets is a new breakthrough launched by Juli Nursadi, Fisheries Lecturer from Lampung State Polytechnic. The concept of Fish Cultivation In a Bucket itself initiated the cultivation of fish as well as plants in the same medium. So here there will be a symbiotic mutualism between fish and plants. Fish get additional food from plants, and plants can get more nutrients from the presence of fish under them.

This concept is very suitable to be used as an object of cultivation during a pandemic, because in addition to being able to improve the economy (the results are sold again, both raw and processed products), the plants and fish produced are guaranteed to be hygienic for their own consumption. In addition, with fish cultivation in a bucket cultivation, the living environment gets additional oxygen, making it healthier for health. other advantages of fish cultivation in a bucket cultivation include:

1. Can be done on narrow land (according to existing settlements in Gresik)

2. Does not require a lot of water.

3. Can be moved

4. Can be a living refrigerator (cool environment).

5. Relatively cheap and easy.

6. Source of protein from fish and vegetables

7. Feed suspended particulate waste for fertilizer for other crops.

8. No electricity for water change.

\section{Catfish}

Clarias or better known as catfish is a fish originating from Africa. This fish is found in fresh water such as rivers with weak currents, ponds, swamps, reservoirs, and flooded rice fields. However, catfish originating from the genus Ariidae may also be found in brackish water (salt water).
Catfish in Indonesia is quite a favorite among some people. This catfish can be a favorite snack, because it tastes delicious but at an affordable price. Unfortunately, catfish cultivation, which is known to be unclean (some are from ponds) makes some people think twice about eating catfish-based dishes.

The potential for catfish to be used as a business in the territory of Indonesia also has considerable land. This is because catfish, which is rich in nutritional benefits but has economic value, is in great demand. Even from year to year, demand for catfish has never been saturated or decreased. Not only that, even more special, catfish has a good survival rate, does not die easily, because it is very suitable to be listed in the business concept.

Catfish is one of the fish that is highly recommended for consumption. Not only does it have a lot of vitamins and other nutritional values, but this delicious catfish also has economic value, so all people can get it. Unlike salmon, which is valuable enough to drain the pocket, so not all people can enjoy it. The various benefits of catfish include.

1. Low in calories and fat

2. In a 100 gram serving of catfish contains only 122 calories and 6.1 grams of fat. This content is very suitable for those who are on a diet, but want a lot of nutrients.

3. Complete protein source

4. Protein in catfish including high quality, 15.6 grams in each tail. This amount is very sufficient to meet the needs of the amino acids needed by the human body.

5. Source of vitamin B-12

6. The content of vitamin B-12 levels in one catfish is quite high, which is $40 \%$. Vitamin B-12 is very important in breaking down food into energy.

7. Low mercury

8. All fish actually contain mercury, but for catfish the mercury contained is relatively low. This was conveyed by the Environmental Protection 
Agency, that catfish is a fish that has the lowest mercury content.

9. Contains healthy fatty acids

10. A catfish contains $220 \mathrm{mg}$ of omega 3 fatty acids and $875 \mathrm{mg}$ of omega 6 fatty acids. Both of these are very important in heart health and cognitive function.

\section{Brazilian Spinach}

Brazilian spinach is a plant species originating from Brazil, South America. This species is easy to live on stem cuttings. This plant is one of the plants that is recommended for consumption because of the myriad benefits it contains.

In general, Brazilian spinach grows rapidly up to $30 \mathrm{~cm}$, with a darn measuring about 2 to $3.5 \mathrm{~cm}$ wide.

Brazilian spinach is one of the plants that is known to be effective in fighting cancer, improving eye health, a source of vitamin $\mathrm{K}$, losing weight, the immune system, helping the immune system and anemia. In addition, Brazilian spinach is also able to overcome the problem of nutrition, maintain stamina, improve oral health and is good for pregnant women

The method of implementing the proposed concept of community service by TI-UMG with the theme Fish farming in buckets is:

1. Provide knowledge about the benefits of self-cultivated fish and plants, here are not only hygienic but can be a source of oxygen in the living environment.

2. Introducing the Fish farming in buckets concept, what fish and plants can be directed to the Cultivation concept.

3. Introducing the cultivation of catfish and Brazilian spinach more specifically. What more benefits are produced by catfish and Brazilian spinach than other fish and plants.

4. Provide knowledge on how to cultivate catfish and Brazilian spinach with aquaponics and how to maintain it sustainably.
5. Provide training on how to cultivate Brazilian catfish and spinach with the concept of Fish farming in buckets (aquaponics).

6. Provide hands-on knowledge on how to take care of Fish farming in buckets so that fish and plants can grow well and provide rich benefits.

7. Socialization of the sustainable use of Brazilian catfish and spinach.

\section{RESULTS}

The existence of limited activities both in the Gresik area and in various parts of Indonesia due to the arrival of the covid-19 virus made this service based on the socialization of Fish farming in buckets encounter many obstacles, one of which was that only 2 invited partners could take the time to contribute to this service activity, namely Yatim Mandiri Foundation and FAMILY WELFARE DEVELOPMENT Yosowilangon.

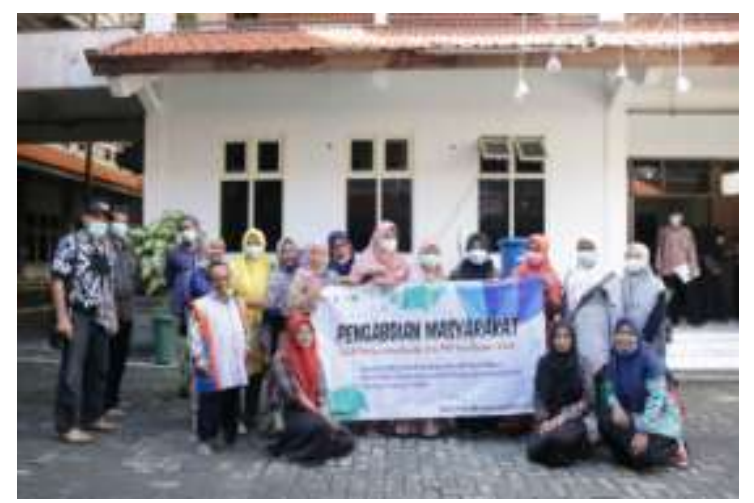

Picture 2. Community Service Team with Independent Orphans and FAMILY WELFARE DEVELOPMENT Yosowilangun

The stages in the Fish farming in buckets Socialization Service among the people of Yosowilangon are described as follows.

1. Attendance Administration

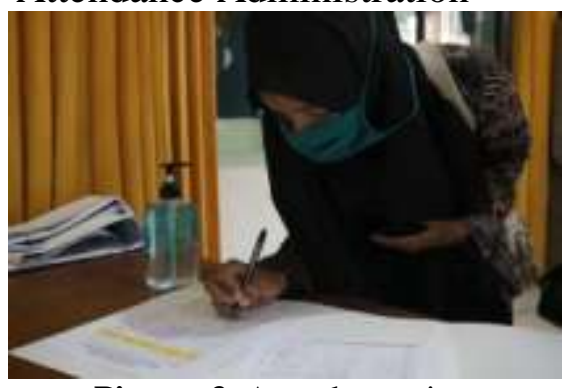

Picture 3. Attendance signature 
Attendance administration in the form of signatures of service participants is the first thing done by the committee, which starts from 08.00 to 09.00 or before the event starts. It aims to prepare participants to be able to attend the workshop from beginning to end.

2. Welcome From The Head of The Study Program

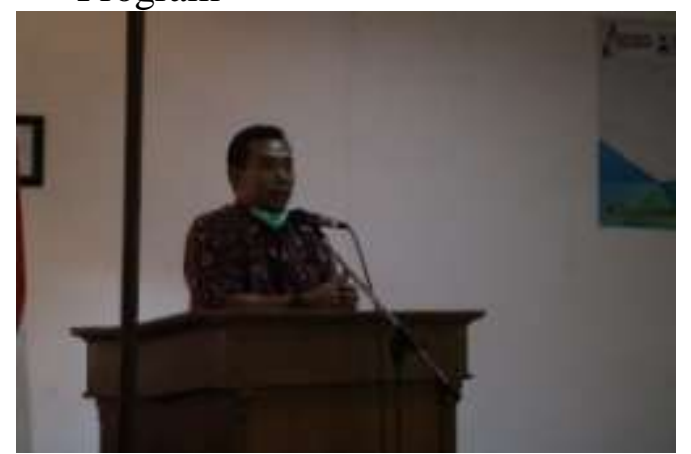

Pic 4. Welcome From The Head of The Study Program

As one of the community services that takes shelter in a university, the first event was opened with a speech from the head of the study program. Because the Head of the Study Program was unable to attend, the remarks were represented by the Secretary of the Study Program. This speech gives the impression that Industrial Engineering has a broad branch of knowledge, one of which can hook another branch of science, namely fisheries, which is dedicated to Bucket Fish Cultivation. This speech, in addition to introducing the service program, is also an introduction to the Industrial Engineering Study Program itself. That Industrial Engineering does not talk about the manufacturing industry, but can also talk about the agricultural industry.

3. Message From The Head Of Yosowilangon Village

4.

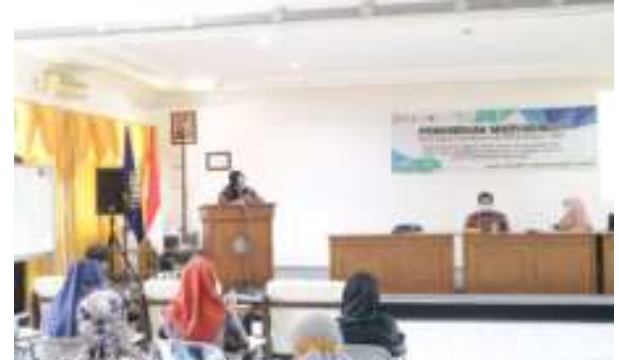

Picture 5. 3. Message from the Head of Yosowilangon Village
The next stage was the speech of the Head of Yosowilangon Village. This speech was delivered because Yatim Mandiri itself is part of the Yosowilangon family, so here the Village Head wants to show his appreciation for the invitation to the community service workshop at UMG Industrial Engineering itself. Fish cultivation in buckets introduced by the Industrial Engineering Study Program is not new, but it is new for the people of Yosowilangon Village. Many of them have already or are still cultivating catfish, but just found out that there is a Fish farming in buckets system that is really suitable for the Gresik area. The bucket, which in fact does not take up space, is enthusiastically welcomed by the residents because even those who have narrow land can cultivate catfish.

\section{Subject Matter}

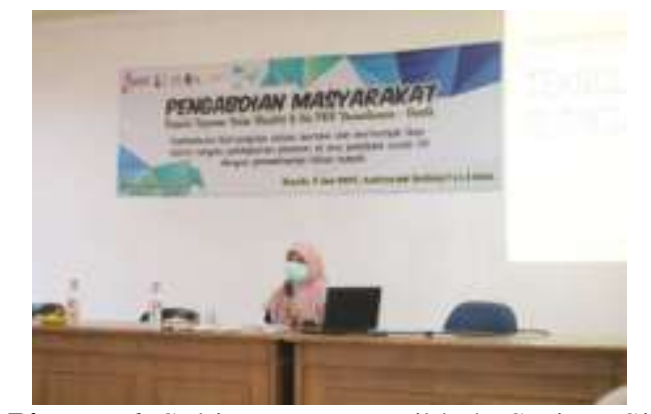

Picture 6. Subject By Dr.Farikhah, S.Pi, M.Si

The material is filled in by Dr. Farikhah, S.Pi, M.Si as an Agriculture Lecturer at UMG who specializes in the world of catfish. The material given by Dr. Farikhah itself includes the development and growth of catfish, how the environment makes catfish grow healthily and fertile. Then accompanied by the development of his own fish farming in buckets.

6. Introduction to Fish farming in Buckets Belonging To The TI-UMG Team

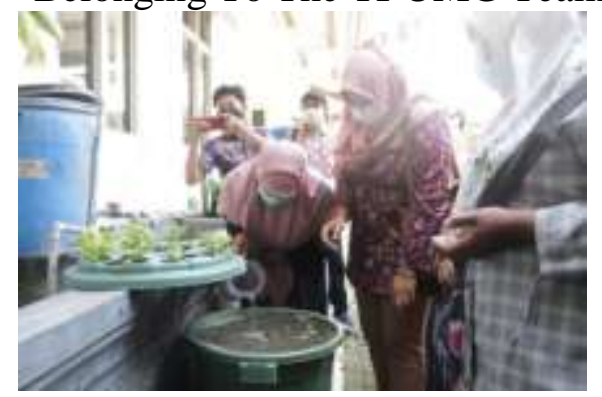

Picture 7. Introduction to Fish farming in buckets By Said Salim Dahda, MT. 
The last event was the introduction of Fish farming in buckets belonging to the TIUMG team which was socialized by $\mathrm{Mr}$. Said Salim Dahda, MT as a lecturer in Industrial Engineering. Unlike other budikdambar, the TI-UMG team's fish farming in buckets uses 4 different media, namely Briquette Charcoal, Cocopeat, Rockwool, Hydroton. In this case, it was found that the planting medium with charcoal briquettes was at least recommended than other planting media, because this media did not provide fertility like other planting media. In this service, Brazilian spinach is used as a plant. Brazilian spinach is preferred because of its high price, and also still lacks market interest (less well known to the Indonesian people) even though it has quite complex properties.

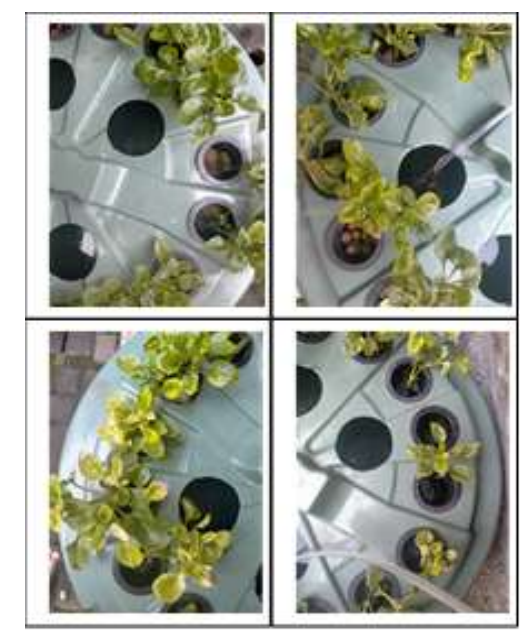

Picture 8. TI-UMG Fish farming in buckets Planting Media

\section{Closing}

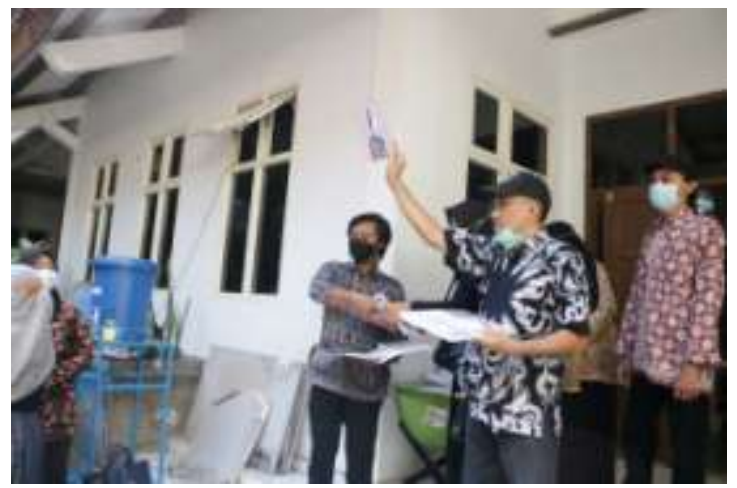

Picture 9. Award Certificates
The next event is giving certificates to participants. This is the last event in the service program with the theme of Fish Cultivation in Buckets by the TI-UMG Service Team, after closing and praying, then participants will be given a certificate that they have studied fish farming in buckets in the TI-UMG program.

\section{CONCLUSION}

The conclusion of this community service program by the UMG Industrial Engineering team is that Fish Cultivation in Buckets is one of the means that can build economic stability due to the impact of COVID-19, especially those affected by layoffs. This can be explained because even with a narrow land we can try to find fortune by raising catfish. Catfish is a fish that is fairly tough and easy to live. The results can be processed for both dry and wet food which can eventually be sold. Not only raising catfish, Fish farming in buckets also provides opportunities for farmers to be able to grow plants on catfish containers. These two camps will contribute to each other in a symbiotic mutualism. Furthermore, for the next service, business continuity will be carried out in the development of the catfish raw material business.

\section{REFERENCES}

Edi Suwiknyo and Jaffry Prabu Prakoso. (2020). Indonesia Officially Recession, Sri Mulyani: Third Quarter Economist Can Minus 2.9 Percent. Bisnis.com https://ekonomi.bisnis.com/. Di akses tanggal 16 September 2020

Hansel Javera. (2020). The Advantages of Catfish Cultivation Business, What Are? OkeFinanace.com.

https://economy.okezone.com. Di akses tamggal 07 Maret 2020)

Hort, M.L. (2013). Edible Plants: An Inspirational Guide to Choosing and Growing Unusual Edible Plants. Plants for A Future.

Leonardo, G.M., \& Rafael, S.S. (2014). Medicinal Plants and Herbal Medicines Usage In The Socioeconomic Reality of 
Northeast Brazilian Cocoa Regi

Munanto Haris. (2020). Brazilian Spinach (Brazilian Spinach). BBPP Ketindan. https://bbppketindan.bppsdmp.pertanian.g o.id/bayam-brazil-brazilian-spinach. Di akses tanggal 26 Oktober 2020.

Nidia Zuraya. (2020). 967 Layoff Victims in Gresik will be included in the PreEmployment Card. Nusantara.com. https://republika.co.id/. Di akses tanggal 14 April 2020

Nur Rohmi Aida. (2020). There are many questions about Fish farming in buckets, here's how to raise catfish and kale in a bucket.

Kompas.com.https://www.kompas.com/ digunakan. Di akses tanggal 04 Mei 2020

Risky Chandra Swari. (2020). 5 Benefits of Catfish for Health that are a pity to miss. HelloSehat.com https://hellosehat.com/. Diakses tanggal 17 September 2020. 